\title{
Synthesis and hydrolysis of auxins and their conjugates with different side-chain lengths: are all products active auxins?
}

\author{
JUTTA LUDWIG-MÜLLER \\ Institute of Botany, Faculty of Biology \\ Technische Universität Dresden, Zellescher Weg 20b, \\ 01062 Dresden, Germany \\ Correspondence: \\ Jutta Ludwig-Müller \\ E-mail: Jutta.Ludwig-Mueller@tu-dresden.de \\ Keywords: auxin conjugation, auxin hydrolysis, \\ biosynthesis, indole-3-acetic acid, indole-3-butyric \\ acid, indole-3-propionic acid, B-oxidation, rooting, \\ transport
}

Received March 16, 2020

Revised July 13, 2020

Accepted July 13, 2020

\begin{abstract}
Plants need hormone substances to regulate a plethora of responses during their life cycle. One major hormone class is called auxin, which is involved in many developmental processes. Besides the major auxin indole-3-acetic acid, there are other auxin-like molecules present in some, but not in all plants, an example would be chlorinated IAA in legumes. Among these are also the auxins with longer chains, indole-3-propionic acid and indole3-butyric acid. The auxin-dependent growth response is dependent on the concentration of the compound. While lower concentrations are mainly growth promoting, high concentrations are actually inhibiting some developmental processes. Therefore, tight control of the auxin concentration is essential for proper growth and development. This can be achieved by altering the amount of active auxin via transport, biosynthesis, degradation or reversible conjugation to small molecules. In addition, plants use auxin during their interaction with the environment, for example during abiotic stresses such as salt, temperature or water stress to adapt the growth responses specifically. Furthermore, auxin is involved in the development of plant disease symptoms, such as tumor growth or aberrant tissue formation. However, together with other plant hormones such as salicylic acid auxin can also modulate disease progression or resistance in different plant - microbe combinations.
\end{abstract}

\section{INTRODUCTION}

$A$ uxins are involved in a plethora of developmental processes and A control organ formation as well as cellular differentiations (1). In addition, auxins seem to be involved in abiotic (2) as well as biotic stress reactions (3). The major auxin in plants is indole-3-acetic acid (IAA), but there are other natural derivatives with similar, lower or even higher bioactivity (4). In any case, the response is strongly dependent on the actual concentration of a given auxin in the plant, since high concentrations of auxin might be inhibiting growth responses (5). Therefore, the tight control of auxin levels is essential, wich can be achieved by either regulating biosynthesis, conjugation to inactive compounds, degradation and transport $(6,7)$. While the other components of the homeostatic system are also important, this review will concentrate mainly on the formation of auxin conjugates and their hydrolysis to the free hormone (Figure 1), but will touch other regulatory aspects such as transport when appropriate (Figure 2). An additional aspect will be the formation of IAA from another auxin with a longer side chain, 


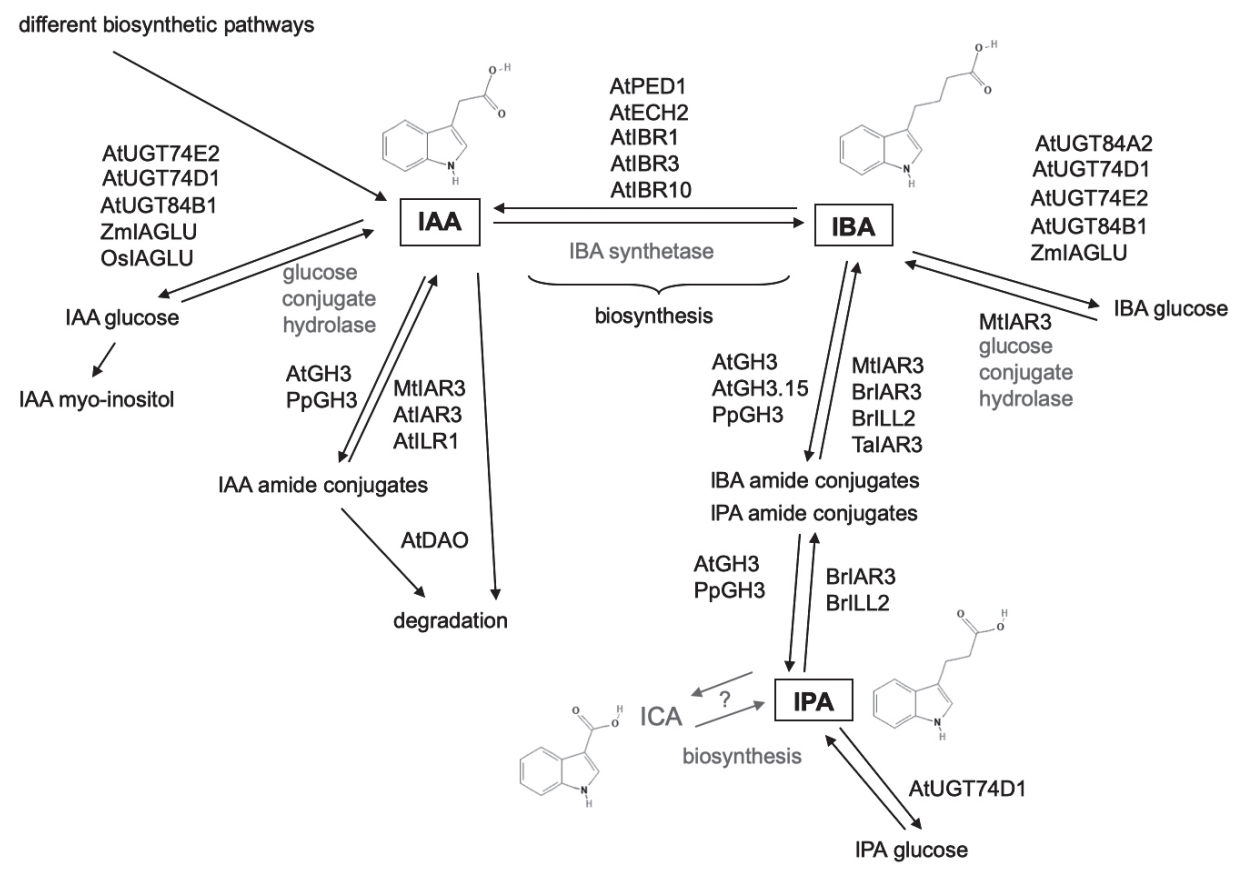

Figure 1. Biosynthesis and metabolism of indole-3-acetic acid (IAA), indole-3-propionic acid (IPA) and indole-3-butyric acid (IBA). High molecular weight conjugates are not shown. Known genes or genes where a function has been assumed in IBA metabolism and which are discussed throughout the review are given. The prefix At stands for Arabiopsis thaliana, Br for Brassica rapa, Mt for Medicago truncatula, Pp for Physcomitrella patens, Ta for Triticum aestivum and Zm for Zea mays. For IBA synthetase only an enzymatic activity is known, therefore given in grey. Whether IPA can be converted to the two unit shorter side-chain derivative indole-3-carboxylic acid (ICA) and vice versa, as IBA and IAA interconversions, has not been shown as yet, therefore is indicated by a question mark. All structures were taken from PubChem (https://pubchem.ncbi.nlm.nih.gov; accessed 17.1.2020).

indole-3-butyric acid (IBA) (8). The question whether the longer-chain auxins that are conjugated and hydrolyzed with high efficiency are auxins per se or rather inactive compounds that need conversion to the active auxin IAA will be discussed.

The auxin IBA has been used for decades in the rooting of cuttings and has thus become of economical importance in horticulture (9). Since its discovery as endogenous compound, its use has been widely accepted in a variety of formulations for many different plant species. In contrast to indole-3-acetic acid (IAA), the major auxin in most plants, it was believed that IBA has a better stability, different metabolism and transport and would thus serve as better source for auxin $(10,11)$. Many studies using so called easy- and difficult-to-root species have been conducted to find a common theme $(12,13)$, but so far no clear-cut evidence has emerged that would allow a conclusion why IBA is sometimes superior to IAA.

Within the last decades it has been accepted that IBA is an endogenous compound in a variety of plant species. The occurrence as well as endogenous levels have been determined by mass spectrometry methods $(10,14)$. The biosynthesis and metabolism of IBA has been investigated by biochemical, molecular and genetic tools $(8,11)$. It has been shown in the model plant Arabidopsis thaliana that the conversion of IBA to IAA most likely excerts its function, but additional data point to a role for IBA independently of IAA. In addition, IBA can be converted to IAA by steps similar to $\beta$-oxidation in peroxisomes $(6,8)$. The biosynthesis of IBA from IAA has been described on an enzymatic level (15), but so far no genes have been cloned. Evidence is emerging for other plant species such as Ory$z a$ sativa (rice), Zea mays (maize) or the model legume Medicago truncatula that IBA acts as plant hormone.

More recently, for two longer side-chain auxins, IBA and indole-3-propionic acid (IPA) the hydrolysis from amino acid conjugates has been described $(16,17)$, but the significance of this reaction is not yet clear and will be discussed below. The structures of all three auxins and their possible conversion to other compounds can be found in Figure 1. Since the identification of these compounds with auxin activity there is a matter of debate as to whether they act as auxin molecules themselves or through the interconversion to IAA, as was described for IBA in Arabidopsis $(18,19)$. However, signaling components specific for IBA have been identified (20) and there is evidence that IBA is transported differently from IAA and this could add to its specific function $(21,22)$. Evidence for both assumptions are presented in one chapter. However, since also the long-chain auxins are conjugated and hydrolysed like IAA, it could well be that there are 


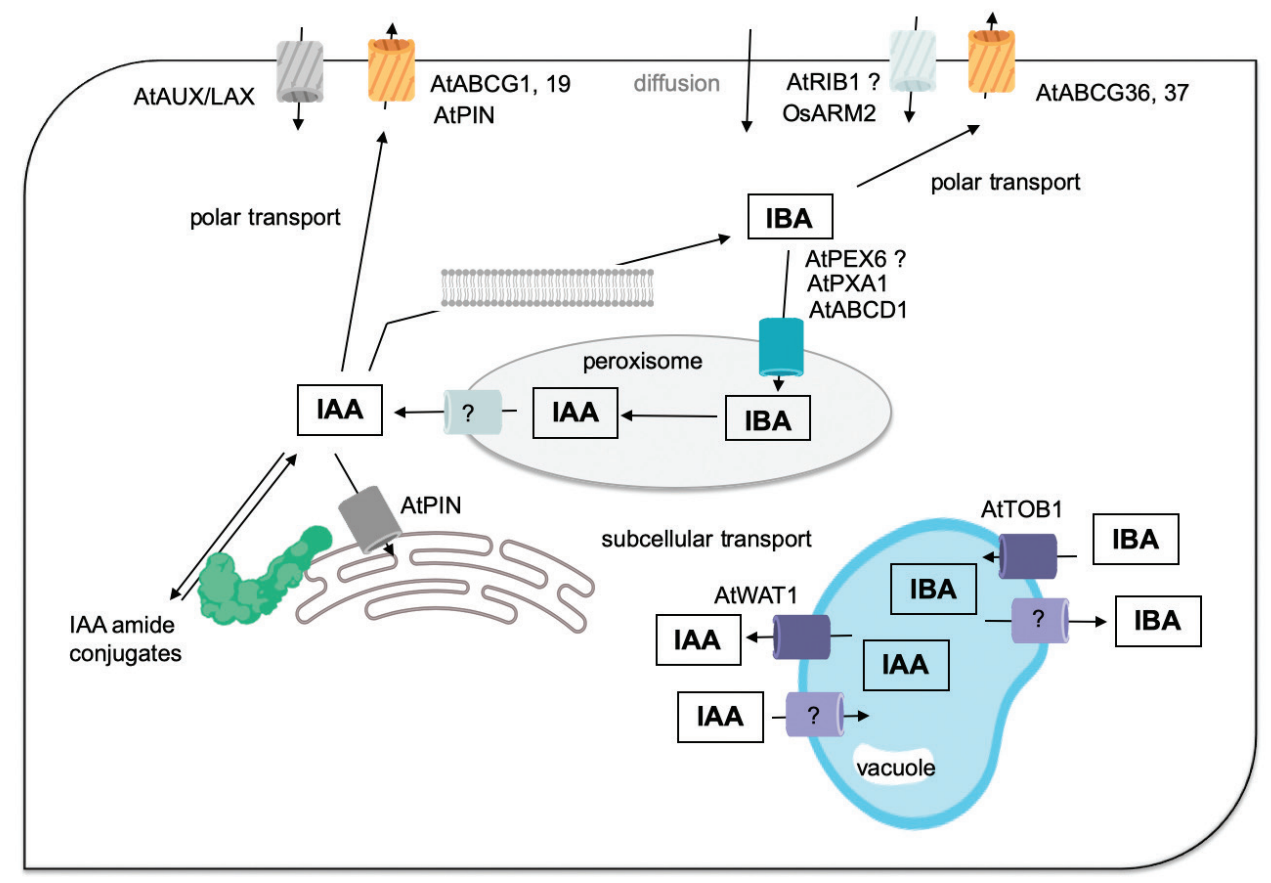

Figure 2. Subcellular compartimentation and intracellular and inter-tissue transport of indole-3-acetic acid (IAA) and indole3-butyric acid (IBA). IAA and IBA are taken up into the cell as well as exported by different carrier proteins. For IBA the influx carrier has not yet been identified in Arabidopsis thaliana, but there is a candidate in Oryza sativa. IAA efflux is determined by the presence of PIN proteins, but also some $A B C$-type transporters, whereas IBA seems to be exclusively exported by ABCG efflux carriers, albeit different ones than $I A A$. IAA conjugates are probably synthesized in the cytosol, but their hydrolysis might take place, at least partially in or at the ER, where some hydrolases are sopposed to reside due to their ER retention sequences. Further, IAA con be transported intot the ER by a specific PIN protein. The vacuolar transport is also indicated, but much less is known here about its possible function for subcellular auxin homeostasis as well as the transporters located in the tonoplast. Some symbols were taken from the free version of biorender (https:/lapp.biorender.com; accessed 4.2.2020). The prefix At stands for Arabidopsis thaliana and Os for Oryza sativa.

functions of these two hormones that have not yet been discovered. For example, IBA is metabolized similar to IAA to form conjugates with amino acids or sugars (7), but in contrast to IAA nothing is so far known about its degradation. In addition, IPA conjugates are strongly cleaved in Brassica rapa (Chinese cabbage) by several hydrolases (17).

\section{FUNCTIONS FOR AUXIN CONJUGATES}

The role of auxin conjugates has been attributed mainly as a storage for the homeostasis of free auxin compounds in normal growth and development (7), but more recently, additional functions in abiotic and biotic stress situation have been found. This is mainly due to the discovery of new enzyme activities for gene families mainly in Arabidopsis, but also in other plant species. Both, the formation of conjugates as well as their hydrolysis has to be taken into account here. Two major classes of auxin conjugates are known, ester and amide bonds with either glucose or amino acids, respectively (7). The formation of glucose conjugates had been attributed mainly to monocot family members, and consequently, the first ester conjugate synthase was found in maize (23). However, simi- lar enzymes were found in dicots, so that characteristic does not seem to fit any more (24). Both classes of conjugates will be described here, but amide conjugates with peptides or proteins will not be included (25-27). Furthermore, the focus will be on the enzymatic activities related to IAA (see Figure 3 for other potential substrates in conjugation).

\section{AMIDE CONJUGATES}

The conjugate formation has been attributed to be a consequence of high auxin levels, since genes encoding members of the GH3 family of auxin conjugate synthetases belong to the auxin-inducible gene families (28). Their active hydrolysis contributes to the levels of free IAA and thus growing tissues, e.g. of Arabidopsis show high expression of such conjugate hydrolases (29). However, at least two amino acid conjugates have been found to be involved in the irreversible degradation pathway (30). Since the conjugate forming and hydrolysing proteins are encoded by large gene families $(29,31-33)$ the study of their role in development is difficult unless multiple mutants are generated in such studies $(29,34)$. The overexpression leads often to stronger phenotypes and was there- 
Table 1. Using TILLING (Targeting Induced Local Lesions IN Genomes) to isolate mutants of three Brassica rapa conjugate hydrolases with the wild type rapid cycling $B$. rapa $R-o-18$ line. The Reverse Genetics facility Rev GenUKat John Innes Centre, was used as a service (Colbert et al.). The technique enables high-throughput screening for induced point mutations, where induction is done by EMS and screening by selectively pooling the DNA and amplifying with fluorescently labelled primers, of which mismatched heteroduplexes were generated between wild type and mutant DNA and these were further identified by sequencing. Using this approach a set of putative mutants was generated for each hydrolase gene; $n-$ total number of mutations.

\begin{tabular}{|lcccc|}
\hline \multirow{2}{*}{ Type of mutation } & & \multicolumn{3}{c|}{ Hydrolase } \\
\cline { 3 - 5 } & & BrIAR3 & BrILL2 & BrILL6 \\
\hline Amino acid change & missense & 12 & 5 & 13 \\
& neutral & 6 & 4 & 3 \\
Premature stop & & 1 & 2 & 1 \\
Splice site & 1 & 0 & 0 \\
Non-coding region & 3 & 2 & 5 \\
$n$ & 23 & 13 & 22 \\
\hline
\end{tabular}

fore also used (35). Also, genes isolated from monocots have been expressed in dicots to study their function (36, 37). In many cases the "typical" auxin deficiency or "high" auxin phenotypes have been described $(7,35)$. However, sometimes the phenotype can only be seen under high auxin conditions $(29,38)$.

Some enzymatic activities have been related to individual auxins, i.e. mainly/only IAA or IBA is conjugated. However, there are also enzymes with a more promiscuous substrate preference towards the carboxylic acid. Some IAA conjugates seem to be involved in tolerance against abiotic stress $(33,39-42)$ while others specifically seem to be important in plant - microbe interactions (43-48). A Populus tremula $x$ tremuloides (poplar) IAA conjugate hydrolase specifically identified undere salt stress conditions conferred salt tolerance to Arabidopsis when heterologously overexpressed (49). In Chinese cabbage the expression of a set of auxin amino acid conjugate hydrolase genes responded to stress hormones, salicylic acid (SA) and jasmonic acid (JA) (50). To study the complex function of this family their activities were identified and shown to be rather specific for longer-chain auxin conjugates with alanine (17). All alanine conjugates could be hydrolysed in planta when incubated with high concentrations of the respective conjugate, but with higher affinity for IPA-Ala, followed by IBA-Ala and last IAAAla (17) and these were confirmed by Molecuar Dynamics simulations where IPA-Ala showed the highst affinity within the binding pocket (51). Furthermore, in a TILLING population (52) several mutations were found that are going to be analysed in the future (Table 1; for details of the methodology see legend). Some mutations leading to a premature stop codon might be the promising ones for future studies unless it was shown that the single amino acid changes could contribute to alterations in enzymatic activities. This might be possible to predict due to previous modelling studies (17). However, it should be noted that even truncation of a Medicago hydrolase gene family only led to changes in enzyme activity and not to complete loss (53).

Some interesting features were attributed during plant defense to amino acid conjugates. On the one hand, their formation can be indirectly linked to defense since overexpression lowers IAA levels and thereby also reduces for example cell wall weakening enzymes, the expansins. With a stronger cell wall the pathogens cannot enter as easily and a basal resistance was conferred (44). On the other hand, a direct effect of the amino acid conjugate of IAA with aspartate (IAA-Asp), that is thought to be part of the degradation route (30) was shown to act as a pathogenicity signal for two different phytopathogens (43). The expression of pathogen-associated genes of Pseudomonas syringae were induced by IAA-Asp and consequently, the knockdown of the responsible $\mathrm{GH} 3$ gene resulted in more resistant plants, whereas addition of IAA-Asp increased the susceptibility (43). Furthermore, the Arabidopsis $\mathrm{GH} 3.5$ protein is at the crossroad of IAA and the defense hormone SA, since it can conjugate both plant hormones to amino acids (45). In addition, differential regulation for conjugate hydrolase as well as for synthetase genes has been reported in the interaction of plants with symbionts such as arbuscular mycorriza and rhizobia $(47,48)$. Highlighting only a few examples for the involvement of GH3 proteins in plant - pathogen interaction already show the diversity of possible functions.

\section{ESTER CONJUGATES}

The upper paragraphs described some examples for the involvement of amino acid conjugates in the stress response of plants, while the next will deal with the formation of ester conjugates (for their possible involvement see Figure 1). The large family of UDP-glucose dependent glycosylases contain several members that are capable to form auxin conjugates with glucose (24) similar to the IAGLU protein from maize, the first in its class to be isolated (23). In addition to the glucose ester, also the formation of conjugates with myo-inositol were found (54). A UDP-glucose transferase from rice altered shoot architecture and root gravitropism when overexpressed (55). The identification of an Arabidopsis homolog UGT-84A1 catalyzing the conjugation of IAA to glucose showed the first time the existence of this reaction on a molecular level in dicot plants (56). Overexpression in the homologous system led to altered phenotypes typical to auxin deficiency (57). While for the formation of amide conjugates IAA as a substrate was in the focus, for the formation of ester conjugates also an important role for IBA 
conjugates with glucose were detected in Arabidopsis (58-60). The closest homolog to the Arabidopsis UDPglucose transferase specific for IAA, UGT84A2, showed high specificity for IBA, but only IAA was tested as other substrate (60), so additional activites could not be found if present. A role for this gene product in the flowering time was proposed bysed on extopic expression (60). In the work using a different glucosyltransferase from Arabidopsis (UGT74E2) it was shown that overexpression led to an altered stress response, i.e. the plants were more tolerant to water stress (58). Furthermore, additional enzymes have been characterized from that large superfamily that catalyse not only the conjugation of IBA and IAA to glucose, but use also IPA as substrate (59). Overexpression of the gene resulted in an accumulation of IBA-glucose as well as a curling leaf phenotype in Arabidopsis, suggesting a physiological role of the encoded enzyme UGT74D1 in affecting the activity of auxins as well (59). Additionally, glycosyltransferases might be involved in the modification of glycoproteins with IAA as shown for Pisum sativum (pea) (61).
While the synthesis of auxin ester conjugates, especially with glucose, is now quite well investigated, the hydrolysis of such conjugates is much less clear. The reaction to conjugate IAA with glucose seems to be an equilibrium reaction and only the formation of IAA myoinositol then shifts the ratio of free to conjugated IAA in favour of the conjugate (62). Therefore, it was long thought that for the first reaction there is no specific enzymatic activity necessary. However, on the enzymatic level, there are reports on the hydrolysis of IAA and IBA glucose described (63). Furthermore, there are reports on the hydrolysis of ester conjugates by the ILR family of auxin amino acid conjugate hydrolases (48).

\section{EVOLUTION OF AUXIN CONJUGATE SYNTHESIS AND HYDROLYSIS}

The development of land plants might be tightly connected with auxin function, but also the specific regulation. Even in algae there might be a regulation because in

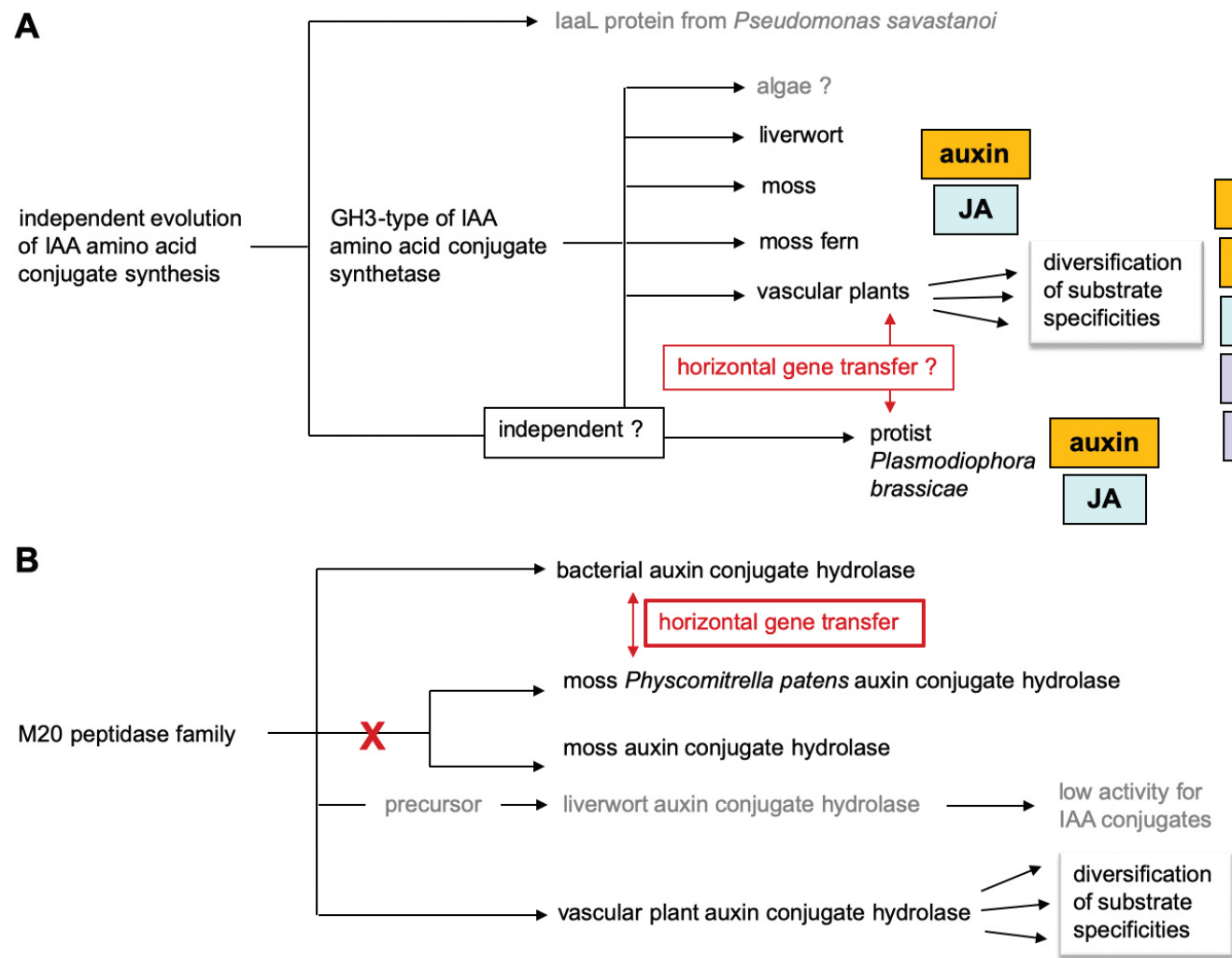

Figure 3. Possible evolution of (A) the auxin amino acid conjugate synthesis and (B) the hydrolysis of auxin amino acid conjugates, both in microbes and plants. For the conjugation at least two completely independent events have led to the evolution of two completely different protein types in a plant pathogenic bacterium, Pseudomonas savastanoi, and in all other organisms to the GH3 family. Whether in the plant pathogenic protist Plasmodiophora brassicae the GH3 activity was independently evolved or acquired by a horizontal gene transfer event, is not clear. The auxin conjugate hydrolases have evolved from the M20 peptidase family, which is present in microbes and plants. Also here, there seem to be two different events in evolution that led to the differentiation of bacterial and plant enzymes since they cluster very differently in phylogenetic analyses (see text). Algae must have conjugate synthesis since in some species auxin conjugates were found. The events shown are not to scale in evolutionary terms; auxin means IAA, IPA, IBA; *makes probably also IPA and in some cases IBA conjugates. 
A

\section{IAA-lysine synthetase \\ (Pseudomonas savastanoi pv. nerii)}

MTAYDMEKEW SRISSTAAKI HONNDFEGFT YODFRTHVPI MDKDGFAAQT ERCLERNERN CLIGFTSGTS GNIKRCYYYY DCEVDEDSSL SNVFRSNGFI LPGDRCANLF TINLFSALNN TITMMAGNCG AHVVSVGDIT LVTKSHFEAL NSIKLNVLLG VPSTILOFIN AMOHNGVHIN IEKVVFTGES LKTFOKKIIR QAFGEQVSIV GVYGSSEGGI LGFTNSPCHT EYEFLSDKYF IEKEGDSILI TSLTRENFTP LLRYRLGDTA TLSMKGDKLY LTDIOREDMS FNFMGNLIGL GIIQQTIKQT LGRSLEIOVH LSVTEERKEL VTVFVQASEV DEDERVRIET AIADIPDIKE AYQKNQGSVS VLRKDARDYA VSERGKMLYI IDRRN

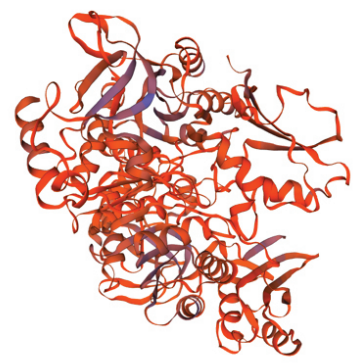

Acyl-CoA synthetase (AMP-forming)/AMP-acid ligase II-like protein 4-coumarate--CoA ligase

AMP-binding domain protein

Phenylacetate-coenzyme A ligase
B

\section{GH3.3 \\ (Arabidopsis thaliana)}

MTVDSALRSP MMHSPSTKDV KALRFIEEMT RNVDFVQKKV IREILSRNSD TEYLKRFGLK GFTDRKTFKT KVPVVTYDDL KPEIQRIANG DRSMILSSYP ITEFLTSSGT SAGERKLMPT IDEDMDRRQL LYSLLMPVMN LYVPGLDKGK ALYFLFVKTE SKTPGGLPAR PVLTSYYKSE QFKRRPYDPY NVYTSPNEAI LCPDSSOSMY TQMLCGLLMR HEVLRLGAVF ASGLLRAIGF LQTNWKELAD DISTGTLSSR ISDPAIKESM SKILTKPDQE LADFITSVCG QDNSWEGIIT KIWPNTKYLD VIVTGAMAQY IPMLEYYSGG LPMACTMYAS SESYFGINLK PMCKPSEVSY TIMPNMAYFE FLPHHEVPTE KSELVELADV EVGKEYELVI TTYAGLNRYR VGDILQVTGF YNSAPQFKFV RRKNVLLSIE SDKTDEAELQ SAVENASLLL GEQGTRVIEY TSYAETKTIP GHYVIYWELL VKDQTNPPND EVMARCCLEM EESLNSVYRQ SRVADKSIGP LEIRVVKNGT FEELMDYAIS RGASINQYKV PRCVSFTPIM ELLDSRVVST HFSPALPHWS PERRR

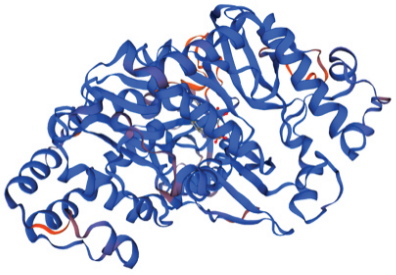

Jasmonic acid-amido synthetase JAR1 AtGH3.15 acyl acid amido synthetase GH3-1 AUXIN CONJUGATING ENZYME

Figure 4. (A) The amino acid sequence of IaaL of Pseudomonas savastanoi (accession KU351686.1) and (B) of Arabidopsis thaliana GH3.3 protein (accession LUHQ0100000) of auxin amino acid conjugate synthetases. The protein from P. savastanoi is 395 amino acids in size while the GH3.3 as one example has 595 amino acids. Below the protein sequences are protein models created in SWISS MODEL (https://swissmodel.expasy.org; accessed on 04.03.2020) for the respective sequence and the three or four closest hits used for the model are shown.

some species auxin conjugates were found (64). A body plan obviously needed the development of a system to control auxin-dependent growth (65). Therefore, not only the biosynthesis and transport of auxin is needed, but also the possibility to control homeostasis on a more specific level. Next to degradation the synthesis of auxin conjugates with amino acids (and sugars?) has been found in many plant species (Figure 3). The biosynthesis, conjugation and degradation were determined (65-68) and it was found that amide conjugate formation seems to be present in the land plant lineage at least with the presence of liverworts $(67,69)$, where the $\mathrm{GH} 3$ proteins are involved in thallus development and seem to be essential for auxin function (69). In moss, specifically Physcomitrella patens the conjugation of IAA, but also IPA and IBA by the same enzymes has been found (38). Interestingly, the two moss GH3 enzymes are also able to conjugate the hormone jasmonic acid to amino acids (38), a characteristic that later in vascular plants has evolved in a larger number of enzymes with higher substrate specificities for the carboxy substrate $(32,70)$. For example, the large $\mathrm{GH} 3$ protein family in Arabidopsis has substrate specificities for JA only in one enzyme (JAR1) (70). IAA can be conjugated by 6 family members (32) and there is a specific enzyme (GH3.15) for IBA amino acid conjugate formation (71). Whether IPA is conjugated by other family members similar with IAA has not been extensively studied. In addition to IAA, salicylic acid can be conjugated by one GH3 family member of Arabidopsis (GH3.5) that can also conjugate IAA (45) and it was shown that a specific conjugate with isochorismic acid and glutamate is a precursor in the SA biosynthesis pathway (72).

Microbes are also able to conjugate IAA. The conjugation of all three auxins (IAA, IPA and IBA) to amino acids has also been found - at least - under in vitro conditions for the pathogenic protist Plasmodiophora brassicae (73) that causes the clubroot disease of Brassica crops. During disease progression the growth promoting plant hormones play a role in forming a hypertrophied root tissue (74). The role for conjugate synthesis in the disease development is as yet unclear, even though one possibility is that JA can also be conjugated to amino acids, except the conjugate with isoleucine which is the active ligand of the plant JA receptor in the defense reponse (75). There are two possibilities how the protist might have acquired the gene, one is via horizontal gene transfer from the host and the other is by independent evolution (Figure 3A). For the horizontal gene transfer scenario via host plants there is some evidence since it was shown that Plasmodiophora can take up and integrate DNA from its host (76). Another, seemingly independent event, has led to the conjugate synthase IaaL from the phytopathogenic bac- 
terium Pseudomonas savastanoi (77). In contrast to the GH3-type the bacterial enzyme conjugates specifically lysine to IAA (Figure 3A). The size of the two proteins differ considerably, while the IaaL protein consists of 395 amino acids, the GH3 family is much larger, i.e. GH3.3 consists of 595 amino acids (Figure 4). Modeling both proteins reveals for the IaaL protein similarities to AcylCoA synthetase (AMP-forming)/AMP-acid ligase II-like protein, 4-coumarate-CoA ligase, AMP-binding domain protein, and Phenylacetate-coenzyme A ligase as the first four hits, in contrast to the GH3 protein (Figure 4).

While the conjugation was unequivocally been shown also in non-vascular land plants, the situation where hydrolysis of conjugates has occurred is not yet clear (78). The amino acid conjugates with IAA and other auxins were found to be hydrolysed back to free auxin by a member of the M20 family of peptidases (7, 79). However, it is thought, at least for Arabidopsis this seems confirmed (30) that two amino acid conjugates of IAA with aspartate and glutamate are substrates for the degradation pathway. In contrast to this species, for example a family of conjugate hydrolases from the model legume plant Medicago is able to partially hydrolyze also IAA-Asp (48). Unlike for conjugate synthesis, the hydrolysis is not yet present in liverworts or mosses $(80,81)$ (Figure 3B). In Marchantia polymorpha (liverworts) the presence of a putative precursor of the M20 peptidase family was detected that had a very low activity for IAA amino acid conjugates (80). However, it could be mutated into a more active variant in vitro. In moss genome sequences no plant type amino acid hydrolase was found (81). However, in moss the presence of conjugate hydrolase sequences was found which had high homology to bacterial type IAA conjugate hydrolases $(79,81)$, which were active. Therefore, it was hypothesized that mosses lost the hydrolases and some (at least Physcomitrella) re-acquired bacterial sequences by horizontal gene transfer (81). As already mentioned, there is an independent evolutionary pathway that occurred in some bacteria since the bacterial sequences cluster far from the typical plant ones even though their activity seems similar (Figure 3B) (82-84). Such bacteria might be associated in the rhizosphere in plants.

\section{THE ROLE OF LONG CHAIN AUXINS}

As pointed out above, there are additional auxin-like molecules with longer side chain, such as IPA and IBA which are also strongly conjugated and hydrolysed with enzymes that have similar or even higher activities than with IAA or IAA conjugates $(16,17)$. Therefore, the possible roles of these auxin derivatives will be discussed below. Details on the biosynthesis, metabolism and transport of IAA, IPA and IBA are summarized in Figures 1 and 2, which are often related on in vitro evidence by heterologous expression of the genes encoding the enzymes involved in the metabolism. Other results are based on mutant analyses or overexpression of genes in planta.

\section{INDOLE-3-BUTYRIC ACID: AN AUXIN TO REGULATE PLANT GROWTH OR ONLY ANOTHER SOURCE OF FREE IAA IN ARABIDOPSIS?}

The reports on the natural occurrence of IPA are scarce and some authors even refer to IPA as an artificial auxin compound (59), but IBA has been reported and quantified in many plant species $(11,14)$. Nevertheless, there are early reports on the bioactivity of IPA and IBA as biocontrol agents in plant - pathogen interactions, but they were added to the plants, so it is not clear whether these two auxins would exert this effect also naturally (85). Even though the existence of IBA in many plant species, including Arabidopsis, has been confirmed (14, 86-89), there are recent reports that are not able to identify IBA in Arabidopsis and other plant species (90). This enigma has been attributed to different growth conditions as well as different methodologies involved in the detection. In addition, radioactively labeled IBA was available which was extensively used for studies on IBA metabolism and transport $(21,86,91-94)$. Newer studies on IBA transport and uptake on the cellular level use also heavy isotope labeled IBA combined with GC-MS or LC-MS $(95,96)$.

$\beta$-Oxidation to IAA. IBA was thought to be more efficient in comparison to IAA in root formation and this was explained by its higher stability against degradation (97). Next, it was suggested that IBA is a precursor of IAA and could be converted to IAA by ß-oxidation, where two carbons are released during each cycle, to have an auxin effect $(8,98)$. A search for "classical" IBA deficient mutants so far not possible due to missing genes for biosynthesis, so the mutants that are available for Arabidopsis are deficient in conversion of IBA to IAA and IBA transport $(8,95)$. Next to the conversion of IBA to IAA it was reported that IAA is also precursor for IBA, not only in vivo $(86,90,91)$ but also in vitro (15). The enzyme was termed IBA synthetase, found in maize and Arabidopsis, so a search was conducted on different Arabidopsis mutants and ecotypes for altered patterns in IAA, IBA and also IBA synthesis determined in vitro using the IBA synthetase assay (99). However, this work did not identify respective mutants that could be used to further elucidate functions.

In Arabidopsis the function of IBA has mainly been attributed to its fuction as precursor for IAA $(8,98,100)$. A summary of the different possibilities of IBA function vs. IBA-to-IAA conversion in Arabidopsis and other plant species during development and biotic interactions is shown in Figure 5. The mutant aim1 defective in $ß$-oxidation showed resistance to 2,4-dichlorophenoxybutyric acid, which is converted to 2,4-dichlorophenoxyacetic acid (2,4-D), a compound with herbicide characteristics, by the $ß$-oxidation pathway and provided thus first indications for this pathway in the conversion of butyric acid side chains (101). The compelling evidence came from long-lasting work in different laboratories showing that 
A Arabidopsis thaliana

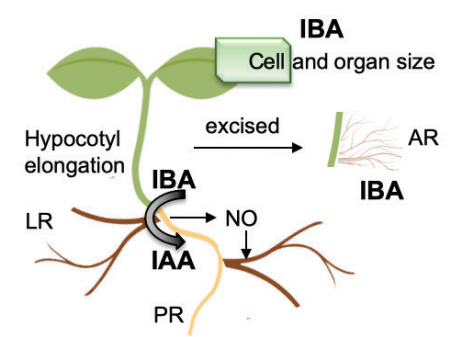

C Biotic interactions

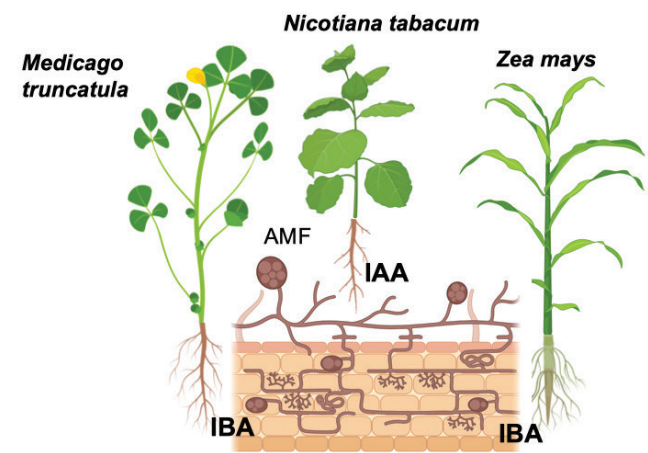

\section{B Other plant species}
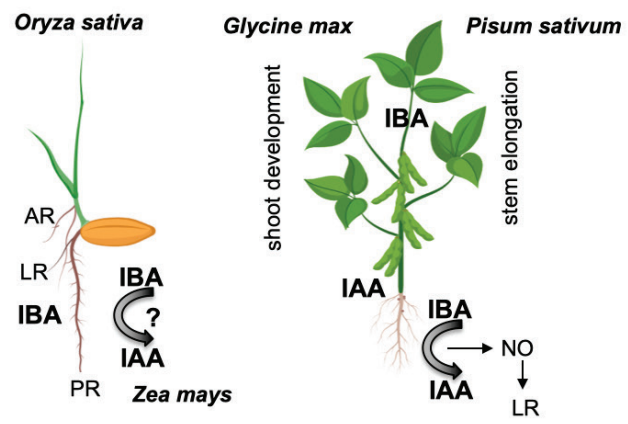

Pisum sativum

Vigna radiata

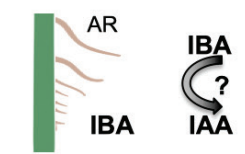

Vigna radiata

Malus sp.

Grevillea sp.

Nicotiana tabacum

Figure 5. A summary of the function of IBA vs IBA-to-IAA conversion in Arabidopsis thaliana (A) and in other plant species during development $(\mathrm{B})$ and interaction with arbuscular mycorrhizal fungi (C). $A M F=$ arbuscular mycorrhizal fungi; $A R=$ adventitious roots; $L R=$ lateral roots; $N O=$ nitric oxide; $P R=$ primary roots. Plant species and AMF cartoon pictures were taken from the free version of biorender (https:/lapp.biorender.com; accessed 4.2.2020).

most traits associated with IBA are reduced in plants with altered conversion of IBA to IAA $(8,18,89,95,98)$. Steps alongside $\beta$-oxidation reactions in the peroxisome were found to be responsible for this conversion $(8,95,98$, 102). Among the functions discussed for IBA-to-IAA conversion in Arabidopsis are lateral and adventitious root formation as well as light regulated hypocotyl elongation $(18,89,103)$, but is also important for cell expansion (104) (Figure 5A).

A different concept has been brought up by Schlicht $e t$ al. (105) who proposed that the rooting effect of IBA in Arabidopsis is due to nitric oxide (NO) as signal which is produced during $ß$-oxidation of IBA to IAA. Rooting was inhibited by an inhibitor of NO production (105). Similarly, in pea root development there was an IBA induced NO burst that led to the induction of lateral roots under osmotic stress (106). These findings are supported by work showing that $\mathrm{NO}$ mediates the auxin response, leading to adventitious root formation. Treatment of mung bean explants with IBA plus an NO donor together resulted in an increased number of adventitious roots compared with explants treated with the NO donor or IBA alone. On the contrary, the action of IBA was significantly reduced by the specific NO scavenger (107).

Signaling pathways differ? However, there are other parts of the IBA vs. IAA reactions involved in signaling and transport that hint towards a separate role of IBA as well, since the two auxin molecules behave differently. While some transport data could be explained by uptake of IBA and then conversion to IAA, other data such as mutant phenotypes that can be rescued by IBA, but not IAA indicate a separate role in other plant species (see below). Furthermore, even in Arabidopsis there are reports where IAA and IBA seem to differ in their responses. For adventitious root formation on Arabidopsis stem segments a role for IBA, but not IAA was demonstrated since IBA induced the response at concentrations where IAA was uneffective (19). If IBA needs to be converted to IAA, it should be active at higher concentrations than IAA. Using known IBA response mutants it was also reported that IBA induced the ectopic formation of metaxylem in the hypocotyl of Arabidopsis without conversion to IAA, but IAA favoured protoxylem formation (108).

The isolation of $i b r 5$ as an Arabidopsis indole-3-butyric acid-response mutant gave new insights in possible signal transduction components for IBA signaling (20). Although this mutant is also less responsive to indole3 -acetic acid, synthetic auxins, auxin transport inhibitors, and the phytohormone abscisic acid, it is a promising specific candidate for the IBA signaling pathway. In accordance with other IBA-response mutants, $i b r 5$ has a long root and a short hypocotyl when grown in the light. In addition, $i b r 5$ displays aberrant vascular patterning and increased leaf serration. IBR5 was identified as dual- 
specificity phosphatase linking auxin and abscisic acid signaling pathways (20). Analysis of an independent mutation in the IBR5 gene called TINKERBELL associated IBR5 negatively with cell and organ size (109). An Arabidopsis MAP kinase (MPK12) interacts with and is dephosphorylated by the phosphatase IBR5 (110). Mutants in the MPK12 gene have altered root phenotypes in response to auxin, so the authors hypothesized that MPK12 is a negative regulator of auxin-induced root formation which is regulated by IBR5 (110). During experiments searching for components of adventitious root formation in Arabidopsis an IBA-inducible phosphatase 2A regulatory subunit was identified that could be part of this signaling chain (19). Other candidates were identified through microarray analysis of adventitious root formation revealed upregulation of PINHEAD/ZWILLE-like proteins after IBA treatment (111). PINHEAD is a member of a family of proteins in Arabidopsis that includes the translation factor eIF2C.

What about differences in transport? Many cellular transporters of IAA do not transport IBA (100). There are three types of transport for IAA and IBA that need to be considered, one is the long distance transport, the second is uptake into the cell and the third uptake into subcellular compartments (see Figure 2) where the auxins can be metabolized $(95,100)$. IBA is converted to IAA in the peroxisome, so for this function the transport across the peroxisome membrane is important. Where the conversion of IAA to IBA takes place is not clear at the moment, but the IBA synthetase enzyme was found to be associated with a microsomal fraction and not with organelles, both in maize and Arabidopsis $(15,99)$. In addition, transport of IAA and IBA into and out of the vacuole has to be considered since recently putative transport molecules have been identified that could be involved in this subcellular transport (95).

Long distance transport differed between IAA and IBA in Arabidopsis stem segments $(21,93)$. In a forward genetic screen a mutant that discriminates between the two known endogenous auxins in Arabidopsis, IAA and IBA, was identified in a screen for root gravitropic mutants and was coined rib1 (resistant to IBA) (94). rib1 was resistant to IBA and 2,4-D, but had a wild-type response to IAA and NAA, therefore, the rib1 mutation specifically affects IBA response in mutant plants (94). The rib1 mutants also showed an increase in hypocotyl length and number of lateral roots but mature plants were phenotypically similar to wild type (112). In addition, it has different transport properties for IAA and IBA $(94,112)$ and is therefore also a good candidate for an IBA influx carrier (95), albeit the respective gene has yet to be identified. Further evidence for differences between IBA and IAA transport in Arabidopsis came from studies using auxin inducible promoter-reporter constructs to monitor the effect of flavonoids on the distribution of exogenously applied IBA or IAA (22). In this work the structural features of flavonoids which are involved in the modulation of auxin distribution or transport $(113,114)$ in Arabidopsis were evaluated. Differences of the same flavonoids on IAA and IBA distribution in leaves and roots were established (22). While IAA is taken up by the AUX/LAX family an IBA uptake carrier has not been identified (see above). Uptake by diffusion is a possibility that cannot be ruled out and work from the 1990s suggest that IBA uptake is higher at low $\mathrm{pH}$ (115) which would be in line with the model for chemiosmotic polar transport of auxins (116). For the efflux of IAA the PIN transporter family is involved whereas IBA seems to be exclusively exported by $\mathrm{ABC}$ transporter types $(95,100)$. However, there are also ABCG type transporters for the efflux of IAA, albeit different ones than for IBA $(96,117)$.

Transport of IBA intracellulary is also necessary to bring IBA into the peroxisomes for $ß$-oxidation and thus conversion to IAA. Mutant screens have identified possible proteins which could have this function for IBA (95, 100). For instance, an $i b r$ mutant defective in the peroxisome transporter PXA1 was identified (118), which is implicated in importing IBA, the jasmonic acid precursor 12-oxophytodienoic acid, and fatty acids (or the corresponding CoA derivatives) into peroxisomes for $ß$-oxidation. pex 6 was also identified in an IBA resistance screen. AtPEX6 encodes an apparent ATPase similar to yeast and human proteins required for peroxisomal biogenesis, which might be also involved in transport processes. PEX1 and PEX6 are interacting ATPases required for matrix protein import (119). While the differences in uptake and efflux as well as intracellular distribution could be signs of the importance of both auxins as individual compounds, there is also the interpretation possible that the specific transport is important to regulate precursor and active auxin (95).

\section{EVIDENCE FOR IBA ACTION IN OTHER PLANT SPECIES}

While in Arabidopsis there is strong genetic evidence that IBA functions as source for IAA, in other plant species the situation can be different. First, there are developmental steps that give indications for IBA as an auxin per se, such as lateral and / or adventitious roots (120122). Second, a variety of stresses induced the synthesis of IBA and consequently the endogenous content of IBA was also increased, whereas IAA was less affected (123). Third, after inoculation of maize roots with an arbuscular mycorrhizal fungus (AMF), the concentrations of IBA, but not IAA, were elevated $(124,125)$ and gene expression was differentially affected when Medicago plants were treated with IBA and AMF (126).

Organ formation. Most investigations have focussed on roots, namely adventitious and lateral root development. In rice a lot of research was focussed on the identification of mutants in lateral root formation (127-130). 
Among these were the mutants arm1, $2(127,128)$ and Irt1, $2(129,130)$. The identification and characterization of such mutants revealed for example the arm 2 gene to encode for a distinct uptake carrier for IBA (128). It was shown that in the mutant arm 2 the acropetal and basipetal transport of IBA but not IAA was defective in roots. In consequence, IBA but not IAA was able to rescue the mutant phenotype of lesser lateral roots (128). The effects of auxins on lateral root initiation and root gravity response in rice were investigated using the mutant lrtl, which fails to form lateral roots and shows a reduced root gravity response (129). Application of IBA to the $l r t 1 \mathrm{mu}-$ tant restored both lateral root initiation and root gravitropism. However, application of IAA restored only root gravitropic response. These results suggest that IBA is more effective than IAA in lateral root formation and that IBA function can be clearly separated from IAA, suggesting that IBA may promote lateral root formation in rice without conversion to IAA (130). A second lateral rootless mutant $l r t 2$ was isolated in screening for 2,4-D resistance in rice (131). lrt2 also failed to form lateral roots and exhibited altered root response to gravity. The effects of the two auxins IAA and IBA on lateral root development were totally different from each other depending on the application method. When the roots were incubated with an auxin solution, IAA inhibited lateral root development, while IBA was stimulatory. In contrast, when auxin was applied to the shoot, IAA promoted lateral root formation, while IBA did not (131). These data again demonstrate that IAA and IBA can be separated in their effects. However, maize seedlings showed similar patterns of primary root elongation and lateral root formation when IAA and IBA were compared (122), even though in other work maize has been shown to alter the root system specifically after increasing IBA when the roots were inoculated with AMF ((124, 125); see also below).

Most studies within the last decades have focussed on using IBA in the induction of adventitious rooting, but only a few studies so far have tried to elucidate the molecular background of adventitious root formation. Application of IBA to cuttings of many plant species results in the induction of adventitious roots and in many cases more efficiently than IAA (9). The induction of adventitious roots was observed after IBA, but much less after IAA application in Vigna radiata (mung bean) $(97,121)$ and Malus sp. (apple) cuttings (132). In the latter plant species IBA could be converted to IAA, but only at a very low percentage of ca $1 \%$ which led the authors to suggest that either IBA itself is active or that it modulates the activity of IAA. In line with these findings, for Grevillea $s p$. it was shown that IBA did not alter the endogenous levels of IAA during the induction of adventitious rooting (13). The Nicotiana tabacum (tobacco) mutant rac did not respond to IBA treatment with the induction of adventitious roots, although cell division was normal (133). Since rac plantlets were not impaired in auxin transport and did not contain altered levels of auxin conjugates, it was as- sumed that the rac mutantion blocks an essential process for auxin induced adventitious root formation. Later experiments showed that the IBA-dependent induction process of adventitious roots occurred in rac shoots, although at a lower rate than in wild type $(134,135)$.

During shoot development of Glycine max (soybean) IBA was found to accumulate in the apical zone, whereas IAA accumulated in the basal zone (136). While there could be the possibility that IBA poses the inactive precursor in the apex, it is more likely that the two auxins have different functions along the shoot. In pea IBA was better in promoting stem elongation of intact plants than IAA (137).

Abiotic and biotic interactions. In maize, IBA biosynthesis and endogenous IBA levels were differentially influenced by abiotic stress factors (123). Therefore, IBA may act as a hormone involved in stress adaptation during growth responses mediated in specific plant species. When seedlings were exposed to drought stress, IBA synthetase activity strongly increased, whereas high amounts of water inhibited IBA synthesis. Consequently, the enzyme activity was enhanced by osmotic stress factors such as $\mathrm{NaCl}$ and sorbitol (123). The maize seedlings showed prominent changes in their root morphology when cultivated in different humidity conditions, i.e. growth under mild drought stress showed the most developed root systems with respect to the number of roots and root hairs, whereas those seedlings cultured on higher amounts of water showed fewer lateral roots, although the main roots were longer (123). Therefore, a correlation between the type of root system and IBA was hypothesized. Similarly, in Arabidopsis IBA synthetase was inducible by drought stress conditions in the two ecotypes Columbia and Landsberg erecta which showed different IBA synthetase activity when cultivated with various degrees of drought stress (99). In this context it might be interesting to note that two mutants $a b a 1$ and $a b a 3$ had higher IBA synthetase activity than wild type (99).

Auxin effects have been associated with development of root architecture (see above). Changes in root morphology after inoculation with AM fungi have been reported by several groups, especially induction of lateral root formation $(138,139)$. Therefore, in many laboratories the effect of mycorrization on IAA levels in host roots was investigated (140). In various investigations e.g. with tomato, no clear effect on IAA levels could be observed (141), but in soybean the IAA levels increased during AMF colonization (142). However, when IBA was measured, the picture was more uniform and there were more distinct differences between colonized and uncolonized roots in different plant species such as maize $(124,125)$ and Medicago $(48,126)$. The increase in endogenous IBA in maize was accompanied by an increase of IBA synthetase activity and treatment of control roots with IBA showed that the phenotype of mycorrhizal maize roots could be mimicked by this auxin at low concentrations (125). The functional role of 
IBA in AMF of maize roots was further corroborated by empoying a halogenated IBA analogue (143). A synthetic IBA analogue, 4,4,4-trifluoro-3-(indole-3)butyric acid (144) had an inhibitory effect on IBA- and AMF-induced root development which coincides with a decrease in the endogenous free IBA and the AM infection rate (143). These results suggested that IBA, but not IAA plays a role in initial processes during $\mathrm{AM}$ colonization of maize roots. To analyze the effect of IBA during AM symbiosis further, the model legume Medicago was used (48). As with maize, IBA was increased throughout AMF colonization, whereas IAA was only at a very late time point. Two transcripts for auxin conjugate hydrolases, which were able to cleave also IBA conjugates, were increased by about 2 -fold in AMF inoculated roots compared to controls (48). Gene expression between AMF colonized and IBA treated plants was investigated using microarray analysis and it was shown that several transcripts were induced both by IBA and AMF colonization (126).

\section{CONCLUSION}

While undoubtly the mentioned compounds exert auxin activites, the precise role for these longer chain auxins has not yet been fully elucidated. In Arabidopsis the major function of IBA seems being a precursor of IAA, albeit there is some evidence for IBA function without having to be converted. In other plant species, the situation is not as clear yet since the function is often more difficult to elucidate on the molecular level. However, the evolution of auxin compounds has resulted in several active species and their role will be subject to future studies.

Acknowledgements: Work in the author's laboratory was supported over the years by the Deutscher Akademischer Austauschdienst (DAAD), the Alexander von HumboldtFoundation (Institutional partnership), by the State of Saxony and by Federal Ministeries of Science and Education as well as Agriculture and Environment.

\section{REFERENCES}

1. DAVIES PJ 1995 Plant Hormones: Physiology, Biochemistry, and Molecular Biology, Kluwer, Dordrecht, The Netherlands

2. SALOPEK-SONDI B, POLLMANN S, GRUDEN K, OELMÜLLER R, LUDWIG-MÜLLER J 2015 Improvement of root architecture under abiotic stress through control of auxin homeostasis in Arabidopsis and Brassica crops. J Endocytobiosis Cell Res 26: 100-111.

3. LUDWIG-MÜLLER J 2015 Bacteria and fungi controlling plant growth by manipulating auxin: Balance between development and defense. J Plant Physiol 172: 4-12.

https://oi.org/10.1016/j.jplph.2014.01.002

4. SIMON S, PETRÁŠEK J 2011 Why plants need more than one type of auxin. Plant Sci 180: 454-460.

https://doi.org/10.1016/j.plantsci.2010.12.007

5. THIMANN KV 1937 On the nature of inhibitions caused by auxin. Am J Bot 24: 407-412.
6. WOODWARD AW, BARTEL B 2005 Auxin: regulation, action and interaction. Ann Bot 95: 707-735. https://doi.org/10.1093/aob/mci083

7. LUDWIG-MÜLLER J 2011 Auxin conjugates: their role for plant development and in the evolution of land plants. J Exp Bot 62: 1757-1773. https://doi.org/10.1093/jxb/erq412

8. BARTEL B, LECLERE S, MAGIDIN M, ZOLMAN BK 2001 Inputs to the active indole-3-acetic acid pool: de novo synthesis, conjugate hydrolysis, and indole-3-butyric acid B-oxidation. J Plant Growth Regul 20: 198-216. https://doi.org/10.1007/s003440010025

9. HARTMANN HT, KESTER DE, DAVIES FT 1990 Plant Propagation: Principles and Practices, Prentice-Hall, Englewood Cliffs, NJ, pp. 246-247.

10. EPSTEIN E, LUDWIG-MÜLLER 1993 Indole-3-butyric acid in plants: occurrence, biosynthesis, metabolism, and transport. Physiol Plant 88: 382-389.

https://doi.org/10.1111/j.1399-3054.1993.tb05513.x.

11. LUDWIG-MÜLLER J 2000 Indole-3-butyric acid in plant growth and development. Plant Growth Regul 32: 219-230. https://doi.org/10.1023/A:1010746806891

12. EPSTEIN E, ZILKAH S, FAINGERSH G, ROTEBAUM A 1993 Transport and metabolism of indole-3-butyric acid in sterile easyto-root and difficult-to-root cuttings of sweet cherry (Prunus avium L.) Acta Hort 329: 292-295. https://doi.org/10.1023/A:1010746806891

13. LUDWIG-MÜLLER J 2003 Peroxidase isoenzymes as markers for the rooting ability of easy-to-root and difficult-to-root Grevillea species. In Vitro Cell Dev Biol-Plant 39: 377-383. https://doi.org/10.1079/IVP2003423

14. BARKAWI LS, TAM Y-Y, TILLMAN JA, PEDERSON B, CALIO J, AL-AMIER H, EMERICK M, NORMANLY J, COHEN JD 2008 A high-throughput method for the quantitative analysis of indole-3-acetic acid and other auxins from plant tissue. Anal Biochem 372: 177-188. https://doi.org/10.1016/j.ab.2007.08.009

15. LUDWIG-MÜLLER J, HILGENBERG W, EPSTEIN E 1995 The in vitro biosynthesis of indole-3-butyric acid in maize. Phytochemistry 40: 61-68. https://doi.org/10.1016/0031-9422(95)00259-A

16. CAMPANELLA JJ, OLAJIDE A, MAGNUS V, LUDWIG-MÜLLER J 2004 A novel auxin conjugate hydrolase from Triticum aestivum with substrate specificity for longer side-chain auxin amide conjugates. Plant Physiol 135: 2230-2240.

https://oi.org/10.1104/pp.104.043398

17. SAVIĆ B, TOMIĆ S, MAGNUS V, GRUDEN K, BARLE K, GRENKOVIĆ R, LUDWIG-MÜLLER J, SALOPEK-SONDI B 2009 Auxin amidohydrolases from Brassica rapa cleave the alanine conjugate of indolepropionic acid as a preferable substrate: a biochemical and modeling approach. Plant Cell Physiol 50: 1587-1599. https://doi.org/10.1093/pcp/pcp101

18. ZOLMAN BK, YODER A, BARTEL B 2000 Genetic analysis of indole-3-butyric acid responses in Arabidopsis thaliana reveals four mutant classes. Genetics 156: 1323-1337.

19. LUDWIG-MÜLLER J, VERTOCNIK A, TOWN CD 2005 Analysis of indole-3-butyric acid induced adventitious root formation on Arabidopsis stem segments. J Exp Bot 56: 2095-2105. https://doi.org/10.1093/jxb/eri208

20. MONROE-AUGUSTUS M, ZOLMAN BK, BARTEL B 2003 IBR5, a dual-specificity phosphatase-like protein modulating auxin and abscisic acid responsiveness in Arabidopsis. Plant Cell 15: 29792991. https://doi.org/10.1105/tpc.017046

21. RASHOTTE AM, POUPART J, WADDELL CS, MUDAY GK 2003 Transport of the two natural auxins, indole-3-butyric acid and 
indole-3-acetic acid, in Arabidopsis. Plant Physiol 133: 761-772. https://oi.org/10.1104/pp.103.022582

22. RUSAK G, CERNI S, STUPIN POLANCEC D, LUDWIGMÜLLER 2010 The responsiveness of the IAA2 promoter to IAA and IBA is differentially affected in Arabidopsis roots and shoots by flavonoids. Biol Plant 54: 403-414. https://doi.org/10.1007/s10535-010-0075-2

23. SZERSZEN JB, SZCZYGLOWSKI K, BANDURSKI RS 1994 iaglu, a gene from Zea mays involved in conjugation of the growth hormone indole-3-acetic acid. Science 265: 1699-1701. https://doi.org/10.1126/science.8085154

24. JACKSON RG, KOWALCZYK M, LI Y, HIGGINS G, ROSS J, SANDBERG G, BOWLES DJ 2002 Over-expression of an Arabidopsis gene encoding a glucosyltransferase of indole-3-acetic acid: phenotypic characterisation of transgenic lines. Plant J 32: 573-583. https://doi.org/10.1046/j.1365-313X.2002.01445.x

25. BIALEK K, COHEN JD 1986 Isolation and partial characterization of the major amide-linked conjugate of indole-3-acetic acid from Phaseolus vulgaris L. Plant Physiol 80: 99-104. https://doi.org/10.1104/pp.80.1.99

26. WALZ A, PARK S, SLOVIN JP, LUDWIG-MÜLLER J, MOMONOKI Y, COHEN JD 2002 A gene encoding a protein modified by the phytohormone indoleacetic acid. Proc Natl Acad Sci USA 99: 1718-1723. https://doi.org/10.1073/pnas.032450399

27. SEIDEL C, WALZ A, PARK S, COHEN JD, LUDWIG-MÜLLER J 2006 Indole-3-acetic acid protein conjugates: Novel players in auxin homeostasis. Plant Biol 8: 340-345. https://doi.org/10.1055/s-2006-923802

28. HAGEN G, KLEINSCHMIDT A, GUILFOYLE T 1984 Auxinregulated gene expression in intact soybean hypocotyls and excised hypocotyls sections. Planta 162: 147-153.

https://doi.org/10.1007/BF00410211

29. RAMPEY RA, LECLERE S, KOWALCZYK M, LJUNG K, SANDBERG G, BARTEL B 2004 A family of auxin-conjugate hydrolases that contributes to free indole-3-acetic acid levels during Arabidopsis germination. Plant Physiol 135: 978-988. https://doi.org/10.1104/pp.104.039677

30. LJUNG K, ÖSTIN A, LIOUSSANNE L, SANDBERG G 2001 Developmental regulation of indole-3-acetic acid turnover in Scots pine seedlings. Plant Physiol 125: 464-475. https://doi.org/10.1104/pp.125.1.464

31. FU X, SHI Z, JIANG Y, JIANG L, QI M, XU T, LI T 2019 A family of auxin conjugate hydrolases from Solanum lycopersicum and analysis of their roles in flower pedicel abscission. BMC Plant Biol 19: 233. https://doi.org/10.1104/pp.125.1.464

32. STASWICK PE, SERBAN B, ROWE M, TIRYAKI I, MALDONADO MT, MALDONADO MC, SUZA W 2005 Characterization of an Arabidopsis enzyme family that conjugates amino acids to indole-3-acetic acid. Plant Cell 17: 616-627. https://doi.org/10.1105/tpc.104.026690

33. FENG S, YUE R, TAO S, YANG Y, ZHANG L, XU M, WANG H, SHEN C 2015 Genome-wide identification, expression analysis of auxin-responsive $\mathrm{GH} 3$ family genes in maize (Zea mays $\mathrm{L}$.) under abiotic stresses. J Integ Plant Biol 57: 783-795. https://doi.org/10.1111/jipb.12327

34. PORCO S, PĚNČÍK A, RASHED A, VOß U, CASANOVASÁEZ R, BISHOPP A, GOLEBIOWSKA A, BHOSALE R, SWARUP R, SWARUP K, PEŇÁKOVÁ P, NOVÁK O, STASWICK P, HEDDEN P, PHILLIPS AL, VISSENBERG K, BENNETT MJ, LJUNG K 2016 Dioxygenase-encoding AtDAO1 gene controls IAA oxidation and homeostasis in Arabidopsis. Proc Natl Acad Sci USA 113: 11016-11021. https://doi.org/10.1073/pnas.1604375113
35. NAKAZAWA M, YABE N, ICHIKAWA T, YAMAMOTO YY, YOSHIZUMI T, HASUNUMA K, MATSUI M 2001 DFL1, an auxin-responsive $\mathrm{GH} 3$ gene homologue, negatively regulates shoot cell elongation and lateral root formation, and positively regulates the light response of hypocotyl length. Plant J 25: 213-221. https://doi.org/10.1046/j.1365-313x.2001.00957.x

36. LUDWIG-MÜLLER J, WALZ A, SLOVIN JP, EPSTEIN E, COHEN JD, DONG W, TOWN CD 2005 Overexpression of the maize iaglu gene in Arabidopsis thaliana alters plant growth and sensitivity to IAA but not IBA and 2,4-D. J Plant Growth Regul 24: 127-141. https://doi.org/10.1007/s00344-004-0006-6

37. IYER M, SLOVIN JP, EPSTEIN E, COHEN JD 2005 Transgenic tomato plants with a modified ability to synthesize indole-3acetyl- $\beta-1-\mathrm{O}-\mathrm{D}$-glucose. J Plant Growth Regul 24: 142-152. https://oi.org/10.1007/s00344-004-0007-5

38. LUDWIG-MÜLLER J, JÜLKE S, BIERFREUND NM, DECKER EL, RESKI R 2009 Moss (Physcomitrella patens) GH3 proteins act in auxin homeostasis. New Phytol 181: 323-338. https://doi.org/10.1111/j.1469-8137.2008.02677.x

39. KIRUNGU JN, MAGWANGA RO, LU P, CAI X, ZHOU Z, WANG X, PENG R, WANG K, LIU F 2019 Functional characterization of Gh_A08G1120 (GH3.5) gene reveal their significant role in enhancing drought and salt stress tolerance in cotton. BMC Genetics 20: 62. https://doi.org/10.1186/s12863-019-0756-6

40. KUMAR R, AGARWAL P, TYAGI AK, SHARMA AK 2012 Genome-wide investigation and expression analysis suggest diverse roles of auxin-responsive $\mathrm{GH} 3$ genes during development and response to different stimuli in tomato (Solanum lycopersicum). Mol Genet Genom 287: 221-235. https://doi.org/10.1007/s00438-011-0672-6

41. KONG W, ZHONG H, DENG X, GAUTAM M, GONG Z, ZHANG Y, ZHAO G, LIU C, LI Y 2019 Evolutionary analysis of GH3 genes in six Oryza species/subspecies and their expression under salinity stress in Oryza sativa ssp. japonica. Plants 8(2): 30. https://doi.org/10.3390/plants8020030

42. PARK JE, PARK JY, KIM YS, STASWICK PE, JEON J, YUN J, KIM SY, KIM J, LEE YH, PARK CM 2007 GH3-mediated auxin homeostasis links growth regulation with stress adaptation response in Arabidopsis. J Biol Chem 282: 10036-10046. https://doi.org/10.1074/jbc.M610524200

43. GONZÁLEZ-LAMOTHE R, EL OIRDI M, BRISSON N, BOUARAB K 2012 The conjugated auxin indole-3-acetic acid-aspartic acid promotes plant disease development. Plant Cell 24: 762-777. https://doi.org/10.1105/tpc.111.095190

44. DING X, CAO Y, HUANG L, ZHAO J, XU C, LI X, WANG S 2008 Activation of the indole-3-acetic acid-amido synthetase GH38 suppresses expansin expression and promotes salicylate- and jasmonate-independent basal immunity in rice. Plant Cell 20: 228 240. https://doi.org/10.1105/tpc.107.055657

45. ZHANG Z, LI Q, LI Z, STASWICK PE, WANG M, ZHU Y, HE Z 2007 Dual regulation role of GH3.5 in salicylic acid and auxin signaling during Arabidopsis-Pseudomonas syringae interaction. Plant Physiol 145: 450-464. https://doi.org/10.1104/pp.107.106021

46. JAGADEESWARAN G, RAINA S, ACHARYA BR, MAQBOOL SB, MOSHER SL, APPEL HM, SCHULTZ JC, KLESSIG DF, RAINA R 2007 Arabidopsis GH3-LIKE DEFENSE GENE 1 is required for accumulation of salicylic acid, activation of defense responses and resistance to Pseudomonas syringae. Plant J 51: 234-246. https://doi.org/10.1111/j.1365-313X.2007.03130.x

47. LIAO D, CHEN X, CHEN A, WANG H, LIU J, LIU J, GU M, SUN S, XU G 2015 The characterization of six auxin-induced tomato $\mathrm{GH} 3$ genes uncovers a member, $\mathrm{SlGH} 3.4$, strongly responsive to arbuscular mycorrhizal symbiosis. Plant Cell Physiol 56: 674687. https://doi.org/10.1093/pcp/pcu212 
48. CAMPANELLA JJ, SMITH SM, LEIBU D, WEXLER S, LUDWIG-MÜLLER J 2008 The auxin conjugate hydrolase family of Medicago truncatula and their expression during the interaction with two symbionts. J Plant Growth Regul 27: 26-38. https://doi.org/10.1007/s00344-007-9027-2

49. JUNGHANS U, POLLE A, DÜCHTING P, WEILER E, KUHLMAN B, GRUBER F, TEICHMANN T 2006 Adaptation to high salinity in poplar involves changes in xylem anatomy and auxin physiology. Plant Cell Environ 29: 1519-1531. https://doi.org/10.1111/j.1365-3040.2006.01529.x

50. SALOPEK-SONDI B, ŠAMEC D, MIHALJEVIĆ S, SMOLKO A, PAVLOVIĆ I, JANKOVIĆ I, LUDWIG-MÜLLER J 2013 Influence of stress hormones on the auxin homeostasis in Brassica rapa seedlings. Plant Cell Rep 32: 1031-1042. https://doi.org/10.1007/s00299-013-1412-7

51. SIMUNOVIC M, ZAGROVIC B, TOMIĆ S 2011 Mechanism and thermodynamics of ligand binding to auxin amidohydrolase. J Mol Recognit 24: 854-861. https://doi.org/10.1002/jmr.1128

52. COLBERT T, TILL BJ, TOMPA R, REYNOLDS S, STEINE MN, YEUNG AT, MCCALLUM CM, COMAI L, HENIKOFF S 2001 High-throughput screening for induced point mutations. Plant Physiol 126: 480-484. https://doi.org/10.1104/pp.126.2.480

53. CAMPANELLA JJ, SIGETHY S, LUDWIG-MÜLLER J (2011) Truncation of Medicago truncatula auxin conjugate hydrolases alters substrate specificity. Plant Mol Biol Rep 29: 745-752. https://doi.org/10.1007/s11105-010-0266-1

54. OSTROWSKI M, CIARKOWSKA A, DALKA A, WILMOWICZ E, JAKUBOWSKA A 2020 Biosynthesis pathway of indole3-acetyl-myo-inositol during development of maize (Zea mays L.) seeds. J Plant Physiol 245: 153082. https://doi.org/10.1016/j.jplph.2019.153082

55. HAI Y, LEUNG DWM, JIAN H, PENG E 2019 Overexpression of OsIAAGLU reveals a role for IAA - glucose conjugation in modulating rice plant architecture. Plant Cell Rep 38: 731-739. https://doi.org/10.1007/s00299-019-02402-4

56. JACKSON RG, LIM E-K, LI Y, KOWALCZYK M, SANDBERG G, HOGGETT J, ASHFORD DA, BOWLES DJ 2001 Identification and biochemical characterization of an Arabidopsis indole3-acetic acid glucosyltransferase. J Biol Chem 276: 4350-4356. https://doi.org/10.1074/jbc.M006185200

57. JACKSON RG, KOWALCZYK M, LI Y, HIGGINS G, ROSS J, SANDBERG G, BOWLES DJ 2002 Over-expression of an Arabidopsis gene encoding a glucosyltransferase of indole-3-acetic acid: phenotypic characterisation of transgenic lines. Plant J 32: 573-583. https://doi.org/10.1046/j.1365-313X.2002.01445.x

58. TOGNETTI VB, VAN AKEN O, MORREEL K, VANDENBROUCKE K, VAN DE COTTE B, DE CLERCQ I, CHIWOCHA S, FENSKE R, PRINSEN E, BOERJAN W, GENTY B, STUBBS KA, INZÉ D, VAN BREUSEGEM F 2010 Perturbation of indole-3-butyric acid homeostasis by the UDP-glucosyltransferase UGT74E2 modulates Arabidopsis architecture and water stress tolerance. Plant Cell 22: 2660-2679.

https://doi.org/10.1105/tpc.109.071316

59. JIN S-H, MA X-M, HAN P, WANG B, SUN Y-G, ZHANG G-Z, LI Y-J, HOU B-K 2013 UGT74D1 is a novel auxin glycosyltransferase from Arabidopsis thaliana. PloS ONE 8: e61705. https://doi.org/10.1371/journal.pone.0061705

60. ZHANG GZ, JIN SH, LI P, YI X, YAN J, LI J, HOU BK 2017 Ectopic expression of UGT84A2 delayed flowering by indole-3-butyric acid-mediated transcriptional repression of ARF 6 and ARF8 genes in Arabidopsis. Plant Cell Rep 36: 1995-2006. https://doi.org/10.1007/s00299-017-2225-x

61. OSTROWSKI M, HETMANN A, JAKUBOWSKA A 2015 Indole-3-acetic acid UDP-glucosyltransferase from immature seeds of pea is involved in modification of glycoproteins. Phytochemistry 117: 25-33. https://doi.org/10.1016/j.phytochem.2015.05.023

62. BAJGUZ A, PIOTROWSKA A 2009 Conjugates of auxin and cytokinin. Phytochemistry 70: 957-969.

https://doi.org/10.1016/j.phytochem.2009.05.006

63. JAKUBOWSKA A, KOWALCZYK S, LEZNICKI AJ 1993 Enzymatic hydrolysis of 4-O and 6-O-indol-3-ylacetyl- $\beta$-D - glucose in plant tissues. J Plant Physiol 142: 61-66. https://doi.org/10.1016/S0176-1617(11)80108-2

64. STIRK W, ARTHUR G, LOURENS A, NOVAK O, STRNAD M, VAN STADEN J 2004 Changes in cytokinin and auxin concentrations in seaweed concentrates when stored at an elevated temperature. J Appl Phycol 16: 31-39. https://doi.org/10.1023/B:JAPH.0000019057.45363.f5

65. COOKE TJ, POLI D, SZTEIN AE, COHEN JD 2002 Evolutionary patterns in auxin action. Plant Mol Biol 49: 319-338. https://doi.org/10.1023/A:1015242627321

66. SZTEIN AE, COHEN JD, SLOVIN JP, COOKE TJ 1995 Auxin metabolism in representative land plants. Am J Bot 82: 1514-1521. https://doi.org/10.1002/j.1537-2197.1995.tb13853.x

67. SZTEIN AE, COHEN JD, GARCÍA DE LA FUENTE I, COOKE TJ 1999 Auxin metabolism in mosses and liverworts. Am J Bot 86: 1544-1555. https://doi.org/ https://doi.org/10.2307/2656792

68. SZTEIN AE, COHEN JD, COOKE TJ 2000 Evolutionary patterns in the auxin metabolism of green plants. Int J Plant Sci 161: 849-859. https://doi.org/10.1086/317566

69. SOLLY JE, CUNNIFFE NJ, HARRISON CJ 2017 Regional growth rate differences specified by apical notch activities regulate liverwort thallus shape. Curr Biol 27: 16-26. https://doi.org/10.1016/j.cub.2016.10.056

70. STASWICK PE, TIRYAKI I, ROWE ML 2002 Jasmonate response locus JAR1 and several related Arabidopsis genes encode enzymes of the firefly luciferase superfamily that show activity on jasmonic, salicylic and indole-3-acetic acids in an assay for adenylation. Plant Cell 14: 1405-1415. https://doi.org/10.1105/tpc.000885

71. SHERP AM, WESTFALL CS, ALVAREZ S, JEZ JM 2018 Arabidopsis thaliana $\mathrm{GH} 3.15$ acyl acid amido synthetase has a highly specific substrate preference for the auxin precursor indole-3-butyric acid. J Biol Chem 293: 4277-4288. https://doi.org/10.1074/jbc.RA118.002006

72. REKHTER D, LÜDKE D, DING Y, FEUSSNER K, ZIENKIEWICZ K, LIPKA V, WIERMER M, ZHANG Y, FEUSSNER I 2019 Isochorismate-derived biosynthesis of the plant stress hormone salicylic acid. Science 365: 498-502.

https://doi.org/10.1126/science.aaw1720

73. SCHWELM A, FOGELQVIST J, KNAUST A, JÜLKE S, LILJA T, BONILLA-ROSSO G, KARLSSON M, SHEVCHENKO A, CHOI SR, DHANDAPANI V, KIM HG, PARK JY, LIM YP, LUDWIG-MÜLLER J, DIXELIUS C 2015 The Plasmodiophora brassicae genome reveals insights in its life cycle and ancestry of chitin synthases. Sci Rep 5: 11153. https://doi.org/10.1038/srep11153

74. LUDWIG-MÜLLER J, PRINSEN E, ROLFE S, SCHOLES J 2009 Metabolism and plant hormone action during the clubroot disease. J Plant Growth Regul 28: 229-244. https://doi.org/10.1007/s00344-009-9089-4

75. FARMER EE 2007 Jasmonate perception machines. Nature 448: 659-660. https://doi.org/10.1038/448659a

76. BRYNGELSSON T, GUSTAFSSON M, GREEN B, LIND C 1988 Uptake of host DNA by the parasitic fungus Plasmodiophora brassicae. Physiol Mol Plant Pathol 33: 163-171. https://doi.org/10.1016/0885-5765(88)90017-3 
77. MATAS IM, PÉREZ-MARTÍNEZ I, QUESADA JM, RODRÍGUEZ-HERVA JJ, PENYALVER R, RAMOS C 2009 Pseudomonas savastanoi pv. savastanoi contains two iaaL paralogs, one of which exhibits a variable number of a trinucleotide (TAC) tandem repeat. Appl Environ Microbiol 75: 1030-1035. https://doi.org/10.1128/AEM.01572-08

78. LUDWIG-MÜLLER J, DECKER EL, RESKI R 2009 Dead end for auxin conjugates in Physcomitrella? Plant Signal Behav 4: 116118. https://doi.org/10.4161/psb.4.2.7536

79. SMOLKO A, LUDWIG-MÜLLERJ, SALOPEK-SONDI B 2018 Auxin amidohydrolases - from structure to function: revisited. Croat Chem Acta 91: 233-239. https://doi.org/10.5562/cca3356

80. CAMPANELLA JJ, KURDACH S, BOCHIS J, SMALLEY JV 2018 Evidence for exaptation of the Marchantia polymorpha M20D peptidase MpILR1 into the tracheophyte auxin regulatory pathway. Plant Physiol 177: 1595-1604. https://doi.org/10.1104/pp.18.00543

81. CAMPANELLA J, KURDACH S, SKIBITSKI R, SMALLEY J, DESIND S, LUDWIG-MÜLLER J 2019 Evidence for the early evolutionary loss of the M20D auxin amidohydrolase family from mosses and horizontal gene transfer from soil bacteria of cryptic hydrolase orthologues to Physcomitrella patens. J Plant Growth Regul 38: 1428-1438.

https://doi.org/10.1007/s00344-019-09945-6

82. CHOU JC, MULBRY WW, COHEN JD 1998 The gene for indole-3-acetyl-L-aspartic acid hydrolase from Enterobacter agglomerans: molecular cloning, nucleotide sequence, and expression in $E s-$ cherichia coli. Mol Gen Genet 259: 172-178. https://doi.org/10.1007/s004380050802

83. CHOU JC, MULBRY WW, COHEN JD 2002 N-carbobenzyloxy-D-aspartic acid as a competitive inhibitor of indole-3-acetylL-aspartic acid hydrolase of Enterobacter agglomerans. Plant Growth Regul 37: 241-248. https://doi.org/10.1023/A:1020872309961

84. LEONG SS, CHIU W, CHOU J 2009 Gene cloning, nucleotide analysis, and overexpression in Escherichia coli of a substrate-specific indole-3-acetyl-L-alanine hydrolase from Arthrobacter ilicis. Bot Stud 50: 11-20

85. MATSUDA K, TOYODA H, NISHIO H, NISHIDA T, DOHGO M, BINGO M, MATSUDA Y, YOSHIDA S, HARADA S, TANAKA H, KOMAI K, OUCHI S 1998 Control of the bacterial wilt of tomato plants by a derivative of 3 -indolepropionic acid based on selective actions on Ralstonia solanacearum. J Agric Food Chem 46: 4416-4419. https://doi.org/10.1021/jf980205f

86. LUDWIG-MÜLLER J, EPSTEIN E 1991 Occurrence and in vivo biosynthesis of indole-3-butyric acid in corn (Zea mays L.). Plant Physiol 97: 765-770. https://doi.org/10.1104/pp.97.2.765

87. LUDWIG-MÜLLER J, SASS S, SUTTER EG, WODNER M, EPSTEIN E 1993 Indole-3-butyric acid in Arabidopsis thaliana. I. Identification and quantification. Plant Growth Regul 13: 179-187. https://doi.org/10.1007/BF00024260

88. LUDWIG-MÜLLER J, COHEN JD 2002 Identification and quantification of three active auxins in different tissues of Tropaeolum majus. Physiol Plant 115: 320-329. https://doi.org/10.1034/j.1399-3054.2002.1150220.x

89. FRICK EM, STRADER LC 2017 Roles for IBA-derived auxin in plant development. J Exp Bot 69: 169-177. https://doi.org/10.1093/jxb/erx298

90. NOVÁK O, HÉNYKOVÁ E, SAIRANEN I, KOWALCZYK M, POSPÍŠIL T, LJUNG K 2012 Tissue-specific profiling of the Arabidopsis thaliana auxin metabolome. Plant J 72: 523-536. https://doi.org/10.1111/j.1365-313X.2012.05085.x

91. LUDWIG-MÜLLER J, EPSTEIN E 1993 Indole-3-butyric acid in Arabidopsis thaliana. II. In vivo metabolism Plant Growth Regul 13: 189-195 https://doi.org/10.1007/BF00024261
92. EPSTEIN E, ACKERMAN A 1993 Transport and metabolism of indole-3-butyric acid in cuttings of Leucadendron discolor. Plant Growth Regul 12: 17-22. https://doi.org/10.1007/BF00144577

93. LUDWIG-MÜLLER J, RAISIG A, HILGENBERG W 1995 Uptake and transport of indole-3-butyric acid in Arabidopsis thaliana: Comparison with other natural and synthetic auxins. J Plant Physiol 147: 351-354. https://doi.org/10.1016/S0176-1617(11)82166-8

94. POUPART J, WADDELL C 2000 The rib1 mutant is resistant to indole-3-butyric acid, an endogenous auxin in Arabidopsis. Plant Physiol 124: 1739-1751. https://doi.org/10.1104/pp.124.4.1739

95. DAMODARAN S, STRADER LC 2019 Indole-3-butyric acid metabolism and transport in Arabidopsis thaliana. Front Plant Sci 10: 851. https://doi.org/10.3389/fpls.2019.00851

96. ARYAL B, HUYNH J, SCHNEUWLY J, SIFFERT A, LIU J, ALEJANDRO S, LUDWIG-MÜLLER J, MARTINOIA E, GEISLER M 2019 ABCG36 / PEN3 / PDR8 is an exporter of the auxin precursor, indole-3-butyric acid, and involved in auxin-controlled development. Front Plant Sci 10: 899. https://doi.org/10.3389/fpls.2019.00899

97. WIESMAN Z, RIOV J, EPSTEIN E 1988 Comparison of movement and metabolism of indole-3-acetic acid in mung bean cuttings. Physiol Plant 74: 556-560 https://doi.org/10.1111/j.1399-3054.1988.tb02018.x

98. ADHAM AR, ZOLMAN BK, MILLIUS A, BARTEL B 2005 Mutations in Arabidopsis acyl-CoA oxidase genes reveal distinct and overlapping roles in ß-oxidation. Plant J 41: 859-874. https://doi.org/10.1111/j.1365-313X.2005.02343.x

99. LUDWIG-MÜLLER J 2007 Indole-3-butyric acid synthesis in ecotypes and mutants of Arabidopsis thaliana under different growth conditions. J Plant Physiol 164: 47-59. https://doi.org/10.1016/j.jplph.2005.10.008

100. STRADER LC, BARTEL B 2011 Transport and metabolism of the endogenous auxin precursor indole-3-butyric acid. Mol Plant 4: 477-486. https://doi.org/10.1093/mp/ssr006

101. RICHMOND TA, BLEECKER AB 1999 A defect in ß-oxidation causes abnormal inflorescence development in Arabidopsis. Plant Cell 11: 1911-1923. https://doi.org/10.1105/tpc.11.10.1911

102. ZOLMAN BK, NYBERG M, BARTEL B 2007 IBR3, a novel peroxisomal acyl-CoA dehydrogenase-like protein required for indole-3-butyric acid response. Plant Mol Biol 64: 59-72. https://doi.org/10.1007/s11103-007-9134-2

103. STRADER LC, WHEELER DL, CHRISTENSEN SE, BERENS JC, COHEN JD, RAMPEY RA, BARTEL B 2011 Multiple facets of Arabidopsis seedling development require indole-3-butyric acid-derived auxin. Plant Cell 23: 984-999. https://doi.org/10.1105/tpc.111.083071

104. STRADER LC, CULLER AH, COHEN JD, BARTEL, B 2010 Conversion of endogenous indole-3-butyric acid to indole-3-acetic acid drives cell expansion in Arabidopsis seedlings. Plant Physiol 153: 1577-1586. https://doi.org/10.1104/pp.110.157461

105. SCHLICHT M, LUDWIG-MÜLLER J, VOLKMANN D, URBACH CB, BALUSKA F 2013 Indole-3-butyric acid induces lateral roots via nitric oxide generation by peroxisomes. New Phytol 200: 473-482. https://doi.org/10.1111/nph.12377

106. KOLBERT Z, BARTHA B, ERDEI L 2008 Osmotic stress- and indole-3-butyric acid-induced $\mathrm{NO}$ generation are partially distinct processes in root growth and development in Pisum sativum. Physiol Plant 133: 406-416. https://doi.org/10.1111/j.1399-3054.2008.01056.x

107. HUANG AX, SHE XP, HUANG C, SONG TS 2007 The dynamic distribution of $\mathrm{NO}$ and NADPH-diaphorase activity during IBA-induced adventitious root formation. Physiol Plant 130: 240-249. https://doi.org/10.1111/j.1399-3054.2007.00897.x 
108. FATTORINI L, DELLA ROVERE F, ANDREINI E, RONZAN M, FALASCA G, ALTAMURA, MM 2017 Indole-3-butyric acid induces ectopic formation of metaxylem in the hypocotyl of Arabidopsis thaliana without conversion into indole-3-acetic acid and with a positive interaction with ethylene. Int J Mol Sci 18(11): 2474. https://doi.org/10.3390/ijms18112474

109. JOHNSON KL, RAMM S, KAPPEL C, WARD S, LEYSER O, SAKAMOTO T, KURATA T, BEVAN MW, LENHARD M 2015 The Tinkerbell (Tink) mutation identifies the dual-specificity MAPK phosphatase INDOLE-3-BUTYRIC ACID-RESPONSE5 (IBR5) as a novel regulator of organ size in arabidopsis. PLoS ONE 10(7): e0131103. https://doi.org/10.1371/journal.pone. 0131103

110. LEE JS, WANG S, SRITUBTIM S, CHEN J-G, ELLIS BE 2009 Arabidopsis mitogen-activated protein kinase MPK12 interacts with the MAPK phosphatase IBR5 and regulates auxin signaling. Plant J 57: 975-985. https://doi.org/10.1111/j.1365-313X.2008.03741.x

111. LYNN K, FERNANDEZ A, AIDA M, SEDBROOK J, TAKASA M, MASSON P, BARTON MK 1999 The PINHEAD/ZWILLE gene acts pleiotropically in Arabidopsis development and has overlapping functions with the ARGONAUTE1 gene. Development 126: 469-481.

112. POUPART J, RASHOTTE AM, MUDAY GK, WADDELL CS 2005 The rib1 mutant of Arabidopsis has alterations in indole3-butyric acid transport, hypocotyl elongation, and root architecture. Plant Physiol 139: 1460-1471.

https://doi.org/10.1104/pp.105.067967

113. PEER WA, BANDYOPADHYAY A, BLAKESLEE JJ, MAKAM SN, CHEN RJ, MASSON PH, MURPHY AS 2004 Variation in expression and protein localization of the PIN family of auxin efflux facilitator proteins in flavonoid mutants with altered auxin transport in Arabidopsis thaliana. Plant Cell 16: 1898-1911. https://doi.org/10.1105/tpc.021501

114. BROWN DE, RASHOTTE AM, MURPHY AS, NORMANLY J, TAGUE BW, PEER WA, TAIZ L, MUDAY GK 2001 Flavonoids act as negative regulators of auxin transport in vivo in Arabidopsis. Plant Physiol 126: 524-535. https://doi.org/10.1104/pp.126.2.524

115. HARBAGE JF, STIMART DP, AUER C 1998 pH affects 1Hindole-3-butyric acid uptake but not metabolism during the initiation phase of adventitious root induction in apple microcuttings. J Am Soc Hort Sci 123: 6-10. https://doi.org/10.21273/JASHS.123.1.6

116. MICHNIEWICZ M, BREWER PB, FRIML J 2007 Polar Auxin Transport and Asymmetric Auxin Distribution. The Arabidopsis Book 2007(5): https://doi.org/10.1199/tab.0108

117. STRADER LC, BARTEL B 2009 The Arabidopsis PLEIOTROPIC DRUG RESISTANCE8/ABCG36 ATP binding cassette transporter modulates sensitivity to the auxin precursor indole3-butyric acid. Plant Cell 21: 1992-2007. https://doi.org/10.1105/tpc.109.065821

118. ZOLMAN BK, SILVA ID, BARTEL B 2001 The Arabidopsis pxa1 mutant is defective in an ATP-binding cassette transporter-like protein required for peroxisomal fatty acid $B$-oxidation. Plant Physiol 127: 1266-1278. https://doi.org/10.1104/pp.010550

119. FABER KN, HEYMAN JA, SUBRAMANI S 1998 Two AAA family peroxins, PpPex1p and PpPex6p, interact with each other in an ATP-dependent manner and are associated with different subcellular membranous structures distinct from peroxisomes. Mol Cell Biol 18: 936-943. https://doi.org/10.1128/mcb.18.2.936

120. WANG H, TAKETA S, MIYAO A, HIROCHIKA H, ICHII M 2006 Isolation of a novel lateral-rootless mutant in rice (Oryza sativa L.) with reduced sensitivity to auxin. Plant Sci 170: 70-77. https://doi.org/10.1016/j.plantsci.2005.08.005
121. LI SW, SHI RF, LENG Y, ZHOU Y 2016 Transcriptomic analysis reveals the gene expression profile that specifically responds to IBA during adventitious rooting in mung bean seedlings. BMC Genomics 17: 43. https://doi.org/10.1186/s12864-016-2372-4

122. MÁRQUEZ G, ALARCÓN MV, SALGUERO J 2016 Differential responses of primary and lateral roots to indole-3-acetic acid, indole-3-butyric acid, and 1-naphthaleneacetic acid in maize seedlings. Biol Plant 60: 367-375. https://doi.org/10.1007/s10535-015-0576-0

123. LUDWIG-MÜLLER J, SCHUBERT B, PIEPER K 1995 Regulation of IBA synthetase from maize (Zea mays L.) by drought stress and ABA. J Exp Bot 46: 423-432. https://doi.org/10.1093/jxb/46.4.423

124. LUDWIG-MÜLLER J, KALDORF M, SUTTER EG, EPSTEIN E 1997 Indole-3-butyric acid (IBA) is enhanced in young maize (Zea mays L.) roots colonized with the arbuscular mycorrhizal fungus Glomus intraradices. Plant Sci 125: 153-162. https://doi.org/10.1016/S0168-9452(97)00064-2

125. KALDORF M, LUDWIG-MÜLLER J 2000 AM fungi might affect the root morphology of maize by increasing indole-3-butyric acid biosynthesis. Physiol Plant 109: 58-67 https://doi.org/10.1034/j.1399-3054.2000.100109.x

126. LUDWIG-MÜLLER J, GÜTHER M 2007 Auxins as signals in arbuscular mycorrhiza formation. Plant Signal Behav 2: 194-196. https://doi.org/10.1111/j.1399-3054.2006.00812.x.

127. CHHUN T, TAKETA S, TSURUMI S, ICHII M 2003 Interaction between two auxin-resistant mutants and their effects on lateral root formation in rice (Oryza sativa L.). J Exp Bot 54: 27012708. https://doi.org/10.1093/jxb/erg306

128. CHHUN T, TAKETA S, ICHII M, TSURUMI S 2005 Involvement of ARM2 in the uptake of indole-3-butyric acid in rice (Oryza sativa L.) roots. Plant Cell Physiol 46: 1161-1164. http://doi.org/10.1093/pcp/pci117

129. CHHUN T, TAKETA S, TSURUMI S, ICHII M 2003 The effects of auxin on lateral root initiation and root gravitropism in a lateral rootless mutant $L r t 1$ of rice (Oryza sativa L.). Plant Growth Regul 39: 161-170. https://doi.org/10.1023/A:1022592511387

130. CHHUN T, TAKETA S, TSURUMI S, ICHII M 2004 Different behaviour of indole-3-acetic acid and indole-3-butyric acid in stimulating lateral root development in rice (Oryza sativa L.). Plant Growth Regul 43: 135-143. https://doi.org/10.1023/B:GROW.0000040120.37448.53

131. WANG H, TAKETA S, MIYAO A, HIROCHIKA H, ICHII M 2006 Isolation of a novel lateral-rootless mutant in rice (Oryza sativa L.) with reduced sensitivity to auxin. Plant Sci 170: 70-77. https://doi.org/10.1016/j.plantsci.2005.08.005

132. VAN DER KRIEKEN WM, BRETELER H, VISSER MHM, MAVRIDOU D 1993 The role of the conversion of IBA into IAA on root generation in apple: introduction of a test system. Plant Cell Rep 12: 203-206. http://doi.org/10.1007/BF00237054

133. LUND ST, SMITH AG, HACKETT WP 1996 Cuttings of a tobacco mutant, $r a c$, undergo cell division but do not initiate adventitious roots in response to exogenous auxin. Physiol Plant 97: 372-380. http://doi.org/10.1034/j.1399-3054.1996.970223.x

134. CABOCHE M, MULLER J-F, CHANUT F, ARANDA G, CIRAKOGLU S 1987 Comparison of the growth promoting activities and toxicities of various auxin analogs on cells derived from wild-type and a non-rooting mutant of tobacco. Plant Physiol 83: 795-800. http://doi.org/10.1104/pp.83.4.795

135. FAIVRE-RAMPANT O, DOMMES J, GASPAR T, D'ANGELI S, FALASCA G, ALTAMURA MM 2003 Rooting blockage in the tobacco $r a c$ mutant occurs at the initiation phase, and induces 
diversion to xylem differentiation. Plant Biosystems 137: 163-174. https://doi.org/10.1080/11263500312331351431

136. JIANG ZF, LIU DD, WANG TQ, LIANG XL, CUI YH, LIU ZH, LI WB 2020 Concentration difference of auxin involved in stem development in soybean. J Integr Agric 19: 953-964. https://doi.org/10.1016/S2095-3119(19)62676-6

137. YANG T, DAVIES PJ 1999 Promotion of stem elongation by indole-3-butyric acid in intact plants of Pisum sativum L. Plant Growth Regul. 27: 157-160. https://doi.org/10.1023/A:1006115414748

138. TISSERANT B, GIANINAZZI S, GIANINAZZI-PEARSON V 1996 Relationships between lateral root order, arbuscular mycorrhiza development and the physiological state of the symbiotic fungus in Platanus acerifolia. Can J Bot 74: 1947-1955. http://doi.org/10.1139/b96-233

139. YANO K, YAMAUCHI A, KONO Y 1996 Localized alteration in lateral root development in roots colonized by an arbuscular mycorrhizal fungus. Mycorrhiza 6: 409-415. https://doi.org/10.1007/s005720050140

140. LUDWIG-MÜLLER J 2010 Hormonal responses in host plants triggered by arbuscular mycorrhizal fungi. Arbuscular Mycorrhi- zas: Physiology and Function, $2^{\text {nd }}$ edition (Kapulnik Y, Koltai H, Eds), Springer, pp 169-190

141. SHAUL-KEINAN O, GADKAR V, GINZBERG I, GRÜNZWEIG JM, CHET I, ELAD Y, WININGER S, BELAUSOV E, ESHED Y, ATZMON N, BEN-TAL Y, KAPULNIK Y 2002 Hormone concentrations in tobacco roots change during arbuscular mycorrhizal colonization with Glomus intraradices. New Phytol 154: 501-508. https://doi.org/10.1046/j.1469-8137.2002.00388.x

142. MEIXNER C, LUDWIG-MÜLLER J, MIERSCH O, GRESSHOFF P, STAEHELIN C, VIERHEILIG H 2005 Lack of mycorrhizal autoregulation and phytohormonal changes in the supernodulating soybean mutant nts1007. Planta 222: 709-715. http://doi.org/10.1007/s00425-005-0003-4

143. FITZE D, WIEPNING A, KALDORF M, LUDWIG-MÜLLER J 2005 Auxins in the development of an arbuscular mycorrhizal symbiosis in maize. J Plant Physiol 162: 1210-1219. http://doi.org/10.1016/j.jplph.2005.01.014

144. KATAYAMA M, KATO K, KIMOTO H, FUJII S 1995 (S)-(+)4,4,4-trifluoro-3-(indole-3-)butyric acid, a novel fluorinated plant growth regulator. Experientia 51: 721-724. https://doi.org/10.1007/BF01941269 